\title{
Influence of Freeze-Thawing and Storage on Human Serum Lipid Analytes
}

\author{
P.C. Ugwuezumba ${ }^{1}$, P. Nwankpa ${ }^{2 *}$, F.C. Emengaha ${ }^{2}$, C.N. Ekweogu ${ }^{2}$, \\ C.C. Etteh ${ }^{2}$ and O.G. Chukwuemeka ${ }^{3}$ \\ ${ }^{1}$ Department of Medical Physiology, ${ }^{2}$ Department of Medical Biochemistry, Imo State \\ University, Owerri \\ ${ }^{3}$ Department of Biochemistry, Michael Okpara University of Agriculture, Umudike Nigeria \\ *Corresponding author
}

\begin{tabular}{|l|}
\hline Key w o r d s \\
$\begin{array}{l}\text { Freeze, Thaw, Lipid } \\
\text { analytes, } \\
\text { Temperature, } \\
\text { Storage }\end{array}$ \\
\hline Article Info \\
\hline $\begin{array}{l}\text { Accepted: } \\
\text { 24 September } 2018 \\
\text { Available Online: } \\
\text { 10 October } 2018\end{array}$ \\
\hline
\end{tabular}

A B S T R A C T
Temperature and storage are important determinants of sample stability which is essential for getting credible concentrations of analytes including those of the lipids. This study examined the influence of freeze-thawing and storage on the concentration human of lipid analytes. The study was conducted using samples from One hundred (50 males and 50 females) randomly selected outpatient participants between the ages of $20-60$ years. Collection of blood samples was done using the antecubital venipuncture. All procedures were in accordance with the guidelines of the Helsinki declaration on human experimentation. Serum sample of each subject was divided into five (5) aliquots. Three (3) aliquots were used for analysis of 7 days storage at $-4^{0} \mathrm{C},-20^{\circ} \mathrm{C}$, and $-70^{\circ} \mathrm{C}$. One (1) aliquot was used for freeze-thawing analysis at $-4^{0} \mathrm{C},-20^{\circ} \mathrm{C}$, and $-70^{\circ} \mathrm{C}$ while the remaining aliquot was used for baseline measurement (control). The lipid analytes examined at various instances included Total Cholesterol (TC), Triglyceride (TG), High density Lipoprotein Cholesterol (HDL-C), Low-density Lipoprotein Cholesterol (LDL-C) and Very Low-density Lipoprotein Cholesterol (VLDL-C). The result showed a statistically significant difference in the concentration of TC, TG, HDL-C and LDL-C for both males and females when frozen at $-4^{0} \mathrm{C}$, significant difference in the concentration of TG and VLDL-C for males and TC, TG, LDL-C and VLDL-C for females when frozen $20^{\circ} \mathrm{C}$. It showed no significant change in the concentration of all the lipid analytes except VLDL-C when frozen at $-70^{\circ} \mathrm{C}$ for both males and females as well as no significant difference in the stability of lipid analytes after 7 days storage at $-4^{0} \mathrm{C},-20^{\circ} \mathrm{C}$ and $-70^{0} \mathrm{C}$ when compared to immediate freezing-thawing cycles of samples at $-4^{0} \mathrm{C},-20^{0} \mathrm{C}$ and $70^{\circ} \mathrm{C}$. In conclusion, $-70^{\circ} \mathrm{C}$ is the optimum temperature for storage of lipid samples in order to maintain stability of the analytes. Also, maintenance of stability of lipid analytes may not be time-dependent but temperature-dependent. It is therefore recommended that additional studies be conducted on extended freezer storage of lipid samples to really ascertain the effect of extended duration in the maintenance of stability of lipid analytes.

\section{Introduction}

Lipid analytes are veritable tools for diagnosis of a number of health disorders mainly cardiovascular diseases. Credibility of biochemical parameters for diagnosis and research purposes depends largely on the stability of representative samples. Most 
medical laboratories are constantly faced with challenges which in most cases prevent sameday processing of samples. These challenges may include equipment breakdown, lack of reagents vis-à-vis thousands of samples received daily for processing. Also need for routine batch analysis for research purposes may sometimes necessitate storage or deepfreezing of samples for an extended duration (Kachhawa et al., 2017).

Stability of serum and plasma analytes during long-term storage is of utmost importance in clinical diagnosis and medical science researches. Samples are stored at different temperatures depending on the duration of storage prior to sample analyses. Temperature and storage are therefore two essential parameters that must be considered in order to maintain the composition and integrity of representative samples during the preanalytical phase (Ono, 1981; Skotol and Nydam, 2005) and guarantee accuracy of analytical results. Studies have shown that $75 \%$ of the errors concerning processing of samples occur in the pre-analytical phase (Bonini et al., 2002; Cuhadar et al., 2013). Samples are usually stored in door $\left(4-8^{0} \mathrm{C}\right)$ of a refrigerator for short durations or in a deep freezer $\left(-20^{\circ} \mathrm{C}\right)$ for longer time periods (Kachhawa et al., 2017). Stability is the capability of keeping the concentrations of analytes minimally affected within an acceptable variation during a period of study (Association of Normatization, 2009).

There is sparse information regarding the stability of biochemical markers such as lipid profile components in serum and plasma following freeze-thawing cycles and storage at different temperatures. Available literatures however reported very controversial findings. In some studies, freezing and storage time increased lipid concentration (Evans et al., 1997; Pini et al., 1990; Tiedink and Katan 1989; Wood et al., 1980); while in other studies, lipid concentrations decreased (Bausserman et al., 1994; Donnelly et al., 1995; Ekbom et al., 1996; Evans et al., 1995; Nanjee and Miller 1990; Simo et al., 2001; Tiedink and Katan 1989); Yet researchers like Kuchmak et al., (1982) and Stokes et al., (1986) found no significant changes in lipid concentration following freezing and storage. In view of the sparse literatures and above controversies therefore, this study was designed to investigate the influence of freezing-thawing and storage on human serum lipid analytes viz; Total Cholesterol (TC), Low Density Lipoproteins (LDL), High Density Lipoproteins (HDL), Very Low Density Lipoproteins (VLDL) and triglycerides.

\section{Materials and Methods}

This was a hospital based study conducted at Imo State University health center. The study included samples from One hundred (100) randomly selected outpatient participants between the ages of $20-60$ years. The aim and objectives of the study were clearly explained to participants in writing and their consent obtained. Ethical consent was also obtained from the University's Ethics Committee. Patients' participation was therefore voluntary, anonymous and confidentiality of the data generated was ensured. Collection of blood samples was done using the antecubital venipuncture. All procedures were conducted in accordance with the guidelines of the Helsinki declaration on human experimentation.

\section{Sample collection and analysis}

Blood samples (total of $6 \mathrm{ml}$ ) of participants were collected in the mornings into $7.5 \mathrm{ml}$ plastic vacuette serum clot activation tubes (BD Vacutainer® Serum; BD, Franklin Lakes NJ, USA). Sample tubes were left in upright position for $30 \mathrm{mins}$ at room temperature to 
allow for complete clot formation, and then were centrifuged at $3500 \mathrm{rpm}$ for $10 \mathrm{mins}$. Serum samples were carefully examined for hemolysis and lipemia to prevent possible interference. Serum sample of each subject was divided into five (5) aliquots. Three (3) aliquots were used for analysis of 7 days storage at $-4^{0} \mathrm{C},-20^{\circ} \mathrm{C}$, and $-70^{\circ} \mathrm{C}$. One (1) aliquot was used for freeze-thawing analysis at $-4^{0} \mathrm{C},-20^{\circ} \mathrm{C}$, and $-70^{\circ} \mathrm{C}$ while the remaining aliquot was used for baseline measurement (control).

Analytes were assayed with reagents manufactured by Roche Diagnostics using kits provided by the manufacturer. Total cholesterol was evaluated by enzymatic colorimetric method. Cholesterol esters were cleaved through the action of cholesterol esterase yielding free cholesterol and fatty acids. Cholesterol oxidase catalyzed the oxidation of cholesterol to form hydrogen peroxide and cholest-4-en-3-one. In the presence of oxidase, the hydrogen peroxide formed affects the oxidative coupling of phenol and 4-aminoantipyrine, forming a quinoneimine red dye. The color intensity is directly proportional to cholesterol concentration, and the absorbance reading is $512 \mathrm{~nm}$. HDL was analyzed by homogeneous colorimetric enzymatic method. In the presence of magnesium ions, dextran sulfate selectively forms water soluble compounds with LDL, VLDL and chylomicrons, which are resistant to polyethylene glycol-modified enzymes. Under the influence of the cholesterol enzyme, the cholesterol esters are decomposed quantitatively into free cholesterol and fatty acids. In the presence of peroxidation, the hydrogen peroxide generated reacts with 4-aminoantipyrine, forming a purple-bluish dye that is directly proportional to cholesterol concentration and is measured photometrically. Triglycerides were measured by colorimetric enzymatic method. This method utilizes the lipoprotein lipase for rapid and complete hydrolysis of triglycerides into glycerol followed by oxidation to dihydroxyacetone phosphate and hydrogen peroxide. The hydrogen peroxide reacts with 4-aminophenone and 4-chlorophenol under peroxidase catalytic action to form a red dye. The concentration of triglycerides is proportional to the intensity of the color generated and measured photometrically. LDL was estimated by the Friedewald et al., (1972) formula: $\mathrm{LDL}=\mathrm{TC}-\mathrm{HDL}-\mathrm{VLDL}$ (Triglycerides/5).

\section{Statistical analysis}

The data generated from the various laboratory analysis were coded in excel sheets and later subjected to statistical analysis using the ANOVA test in the Statistical Packages for Social Sciences (SPSS) version 21 software. Mean \pm SEM were calculated and mean values were considered to be statistically significant at $95 \%$ level of confidence $(\mathrm{P} \leq 0.05)$.

\section{Results and Discussion}

Lipid profile assessment is an essential parameter which helps in the diagnosis of cardiovascular diseases (Laakso et al., 1993; Shai et al., 2004; Pischon et al., 2005; Walldius and Jungner, 2006) and to a lesser extent diagnosis of diabetes (Jiang et al., 2004; Bruno et al., 2006) and cancer (Santos and Schulze 2012; Muntoni et al., 2009). The temperature at which samples are stored constitutes an important pre-analytical variable that may affect analysis results in the clinical biochemistry laboratory setting. This study was undertaken with the aim of examining the influence of repeated freezethawing and storage on the concentration of lipid analytes of human serum. The lipid analytes investigated include total cholesterol (TC), Low density lipoprotein (LDL), High density lipoproteins (HDL), Very low density 
lipoproteins (VLDL) and triglycerides. This study revealed a statistically significant difference in the concentration of TC, TG, HDL-C and LDL-C for both males and females when frozen at $-4^{0} \mathrm{C}$, significant difference in the concentration of $\mathrm{TG}$ and VLDL-C for males and TC, TG, LDL-C and VLDL-C for females when frozen $-20^{\circ} \mathrm{C}$. It showed no significant change in the concentration of all the lipid analytes except VLDL-C when frozen at $-70^{\circ} \mathrm{C}$ for both males and females. This finding can be said to be in line with the reports of Paltiel et al., (2008), Comstock et al., 2001), Rudy et al.,
(2016), Sasaki and Capuzzo (1987)and Metherel et al., (2013). According to Paltiel et al., and Comstock et al., serum cholesterol and triglyceride maintain stability after storage in freezer at $-80^{\circ} \mathrm{C}$. Following investigations of various methods of maintaining stability of samples, Rudy et al., reported that immediate freezing at $-80^{\circ} \mathrm{C}$ is ideal to prevent changes in total lipids and fatty acid content while Sasaki and Capuzzo suggested that tissue samples be frozen at $-80^{\circ} \mathrm{C}$ upon collection or as soon as possible after sampling or death, Metherel et al., recommended freezing at $80^{\circ} \mathrm{C}$ when compared to $-20^{\circ} \mathrm{C}$ (Table 1-4).

Table.1 Effect of freezing to thawing on lipid profile of human male blood sample

\begin{tabular}{|l|l|l|l|l|}
\hline Lipid Parameter & Control (fresh) & $-4^{0} \mathrm{C}$ & $-20^{\circ} \mathrm{C}$ & $-70^{0} \mathrm{C}$ \\
\hline Total Cholesterol (TC) & $165.67 \pm 0.51$ & $150.41 \pm 0.02^{*}$ & $160.27 \pm 0.01$ & $162.22 \pm 0.01$ \\
\hline Triglyceride (TG) & $120.17 \pm 0.35$ & $95.26 \pm 0.04^{*}$ & $80.24 \pm 0.21^{*}$ & $113.25 \pm 0.22$ \\
\hline HDL-C & $59.63 \pm 0.54$ & $50.21 \pm 0.03^{*}$ & $55.87 \pm 0.04$ & $57.78 \pm 0.04$ \\
\hline LDL-C & $101.72 \pm 0.40$ & $90.10 \pm 0.02^{*}$ & $95.72 \pm 0.03$ & $98.62 \pm 0.01$ \\
\hline VLDL-C & $19.83 \pm 0.56$ & $15.24 \pm 0.08$ & $12.51 \pm 0.05^{*}$ & $9.70 \pm 0.11^{*}$ \\
\hline
\end{tabular}

Values are expressed as mean $\pm \mathrm{SD}, \mathrm{n}=50, *=$ significantly different from control $(\mathrm{p}<0.05)$.

Table.2 Effect of freezing-thawing on lipid profile of human female blood sample

\begin{tabular}{|l|l|l|l|l|}
\hline Lipid Parameter & Control (fresh) & $-4^{0} \mathrm{C}$ & $-20^{0} \mathrm{C}$ & $-70^{0} \mathrm{C}$ \\
\hline Total Cholesterol (TC) & $180.21 \pm 2.01$ & $152.31 \pm 0.02^{*}$ & $166.28 \pm 0.01^{*}$ & $177.26 \pm 0.01$ \\
\hline Triglyceride (TG) & $115.34 \pm 1.50$ & $98.15 \pm 0.01^{*}$ & $84.55 \pm 0.06^{*}$ & $110.34 \pm 0.21$ \\
\hline HDL-C & $65.62 \pm 1.18$ & $54.26 \pm 0.03^{*}$ & $57.73 \pm 0.04$ & $58.42 \pm 0.04$ \\
\hline LDL-C & $110.15 \pm 1.40$ & $91.82 \pm 0.02^{*}$ & $99.18 \pm 0.03^{*}$ & $104.68 \pm 0.01$ \\
\hline VLDL-C & $21.72 \pm 0.52$ & $19.62 \pm 0.01$ & $16.83 \pm 0.05^{*}$ & $11.27 \pm 0.06^{*}$ \\
\hline
\end{tabular}

Values are expressed as mean $\pm \mathrm{SD}, \mathrm{n}=50, *=$ significantly different from control $(\mathrm{p}<0.05)$.

Table.3 Effect of 7 day storage at different temperatures on lipid profile of human male blood sample

\begin{tabular}{|l|l|l|l|l|}
\hline Lipid Parameter & Control (fresh) & $-4^{0} \mathrm{C}$ & $-20^{\circ} \mathrm{C}$ & $-70^{0} \mathrm{C}$ \\
\hline Total Cholesterol (TC) & $165.67 \pm 0.51$ & $152.11 \pm 0.04$ & $162.58 \pm 0.04$ & $165.51 \pm 0.03$ \\
\hline Triglyceride (TG) & $120.17 \pm 0.35$ & $93.76 \pm 0.03$ & $80.26 \pm 0.06$ & $115.26 \pm 0.02$ \\
\hline HDL-C & $59.63 \pm 0.54$ & $50.29 \pm 0.02$ & $48.78 \pm 0.03$ & $56.17 \pm 0.06$ \\
\hline LDL-C & $101.72 \pm 0.40$ & $89.68 \pm 0.05$ & $91.29 \pm 0.03$ & $95.62 \pm 0.04$ \\
\hline VLDL-C & $19.83 \pm 0.56$ & $14.91 \pm 0.04$ & $11.62 \pm 0.02$ & $10.74 \pm 0.04$ \\
\hline
\end{tabular}

Values are expressed as mean $\pm \mathrm{SD}, \mathrm{n}=50$. 
Table.4 Effect of 7 day storage at different temperatures on lipid profile of Human female blood sample

\begin{tabular}{|l|l|l|l|l|}
\hline Lipid Parameter & Control (fresh) & $-4^{0} \mathrm{C}$ & $-20^{0} \mathrm{C}$ & $-70^{\circ} \mathrm{C}$ \\
\hline Total Cholesterol (TC) & $180.21 \pm 2.01$ & $150.24 \pm 0.04$ & $160.28 \pm 0.04$ & $177.21 \pm 0.31$ \\
\hline Triglyceride (TG) & $115.34 \pm 1.50$ & $92.16 \pm 0.04$ & $81.68 \pm 0.06$ & $108.18 \pm 0.52$ \\
\hline HDL-C & $65.62 \pm 1.18$ & $53.18 \pm 0.02$ & $51.64 \pm 0.03$ & $57.11 \pm 0.64$ \\
\hline LDL-C & $110.15 \pm 1.40$ & $86.61 \pm 0.05$ & $98.08 \pm 0.03$ & $103.22 \pm 0.48$ \\
\hline VLDL-C & $21.72 \pm 0.52$ & $18.44 \pm 0.05$ & $14.29 \pm 0.02$ & $10.45 \pm 0.43$ \\
\hline
\end{tabular}

Values are expressed as mean $\pm \mathrm{SD}, \mathrm{n}=50$.

The present study further revealed no statistically significant difference in the concentration of lipid analytes after 7 days storage at $-4^{0} \mathrm{C},-20^{\circ} \mathrm{C}$ and $-70^{\circ} \mathrm{C}$ when compared to immediate freezing/thawing cycles of samples at $-4^{0} \mathrm{C},-20^{\circ} \mathrm{C}$ and $70^{\circ} \mathrm{C}$. This finding is in tandem with the reports of Zivkovic et al., (2009) and Heinz et al., (1995). Storage for 1 week at $-4^{0} \mathrm{C}$, $20^{\circ} \mathrm{C}$ and $-80^{\circ} \mathrm{C}$ according to Zivkovic et al., had only minor effects on serum lipid composition, with $0-4 \%$ of metabolites affected in most lipid classes. Heinz et al., reported stability of TC, TG and lipoproteins after 7 days storage in the refrigerator. Also in line with the present finding are the reports of Evans et al., (1995), Franca et al., (2018), Paltiel et al., (2008), Kachhawa et al., (2017), and Cuhadar et al., (2013). According to Evans et al., there is no significant difference in the stability of TC and TG after 10 days storage at $-4^{0} \mathrm{C}$ and 3 months storage at $20^{\circ}$ C. Conversely, studies conducted by Tiedink and Katan (1989), Ferrario (1999) and Maduka et al., (2009) revealed changes in the stability of lipid analytes especially the lipoprotein fractions following freezer storage for 11 to 27 weeks, 14 days at $-20^{\circ} \mathrm{C}$ and 51 days respectively.

In conclusion, this study revealed a statistically significant difference in the concentration of most lipid analytes when freeze-thawed at $-4^{0} \mathrm{C}$ and $-20^{\circ} \mathrm{C}$ and no significant difference when freeze-thawed at -
$70^{0} \mathrm{C}$ compared to control (fresh samples). It also showed no significant difference in the concentration of lipid analytes after 7 days storage at $-4^{0} \mathrm{C},-20^{\circ} \mathrm{C}$ and $-70^{\circ} \mathrm{C}$ compared to samples immediately freeze-thawed at these temperatures. The study therefore indicated that $-70^{\circ} \mathrm{C}$ is the optimum temperature for storage of lipid samples in order to maintain stability of the analytes. Also that maintenance of stability of lipid analytes is may not be time-dependent but temperature-dependent. We therefore recommend storage of lipid samples at $-70^{\circ} \mathrm{C}$ (or between $-70^{\circ} \mathrm{C}$ to $-80^{\circ} \mathrm{C}$ ) and the need for additional studies to embark on long-term storage of lipid samples to really ascertain the effect of extended duration in the maintenance of stability of lipid analytes.

\section{References}

Association of Normatization. 2009. Clinical Laboratory - Pre-analytica. Part 4 Rejection criteria for biological samples. Norma Mercosul. NM. 1: 311347.

Bausserman, L. L., Saritelli, A.L., and Milosavljevic, D. 1994. High- density lipoprotein subfractions measured in stored serum. Clinical Chemistry, 40(9), 1713-1716.

Bonini, P., Plebani, M., Ceriotti, F., Rubboli, F. 2002. Errors in laboratory medicine. Clin Chem 48: 691- 698. 
Bruno, G., Merletti, F., Biggeri, A., Bargero, G., Prina-Cerai, S., et al., 2006. Effect of age on the association of non-highdensity lipoprotein cholesterol and apolipoprotein B with cardiovascular mortality in a Mediterranean population with type 2 diabetes: the Casale Monferrato study. Diabetologia 49: 937-944.

Comstock, G. W, Burke, A. E, Norkus, E. P, Gordon, G.B, Hoff man, S.C, Helzlsouer, K.J. 2001. Effects of repeated freeze-thaw cycles on concentrations of cholesterol, micronutrients, and hormones in human plasma and serum. Clin Chem; 47:13942.

Cuhadar, S., Koseoglu, M., Atay, A., Dirican, A. 2013. The effect of storage time and freeze-thaw cycles on the stability of serum samples. Biochem Med (Zagreb); 23: 70-7.

Donnelly, J. G., Soldin, S. J., Nealon, D. A., and Hicks, J. M. 1995. Stability of twenty-five analytes in human serum at 22 degrees $\mathrm{C}, 4$ degrees $\mathrm{C}$, and -20 degrees C. Pediatric Pathology and Laboratory Medicine, 15(6), 869-874.

Ekbom, T., Lindholm, L. H., Lanke, J., and Nilsson-Ehle, P. 1996. Decrease in high density lipoprotein cholesterol during pro- longed storage. CELL Study Group. Scandinavian Journal of Clinical and Laboratory Investigation, 56(2), 97-101.

Evans, K., Mitcheson, J., and Laker, M.F. 1997. Effect of storage at -70 degrees $C$ on lipid, lipoprotein and apolipoprotein concentrations. Clinica Chemica Acta, 258(2), 219-229.

Evans, K., Mitcheson, J., Laker, M.F. 1995. Effect of storage at $4{ }^{\circ} \mathrm{C}$ and $-20^{\circ} \mathrm{C}$ Con lipid, lipoprotein, and apolipoprotein concentrations. Clin Chem. 41: 392396.
Ferrario, M. 1999. Quality Assessment of total cholesterol measurements; In WHO Monica project. $105-130$.

Franca, C.N., Mendes C.C., Ferreira, C.E.S. 2018. Time collection and storage conditions of lipid profile. Brazilian Journal of Medical and Biological Research; 51(3): e6955.

Frieldewald, W. T., Levy, R. I., Fredrickson, D. S. 1972. Estimation of the concentration of low density lipoprotein cholesterol in plasma without use of the preparative ultracentrifuge. Clin.Chem. 18: 499 - 502 .

Heins, M., Heil, W., Withold, W. 1995. Storage of serum or whole blood samples? Effects of time and temperature on 22 serum analytes. Eur $J$ Clin Chem Clin Biochem. 33: 231-238.

Jiang, R., Schulze, M.B., Li, T., Rifai, N., Stampfer, M.J., et al., 2004. Non-HDL cholesterol and apolipoprotein B predict cardiovascular disease events among men with type 2 diabetes. Diabetes Care 27: 1991-1997.

Kachhawa, K., Kachhawa, P., Varma, M. Behera, R., Agrawal, D., Kumar, S. 2017. Study of the Stability of Various Biochemical Analytes in Samples Stored at Different Predefined Storage Conditions at an Accredited Laboratory of India. Journal of Laboratory Physicians; 9 (1): 11 - 15.

Kuchmak, M., Taylor, L., and Olansky, A.S. 1982. Suitability of frozen and lyophilized reference sera for cholesterol and triglyceride determinations. Clinica Chemica Acta, 120(2), 261-271.

Laakso, M., Lehto, S., Penttila, I., Pyorala, K. 1993. Lipids and lipoproteins predicting coronary heart disease mortality and morbidity in patients with non-insulindependent diabetes. Circulation 88: 1421-1430. 
Maduka, I. C., Neboh, E. E., Ikekpeazu, E.J., Muoghalu, C. V., Ejezie, F.E., Ufelle, S.A. 2009. The effect of sample storage on total cholesterol and HDLC Assays. Journal of Biochemical Sciences; 1 (2): $1-5$.

Metherel, A.H., Aristizabal, J.J., Stark, K.D. 2013. EPA and DHA levels in whole blood decrease more rapidly when stored at $-20^{\circ} \mathrm{C}$ as compared with room temperature, 4 and $-75^{\circ}$ C. Lipids. 48: 1079 - 1091 .

Muntoni, S., Atzori, L., Mereu, R., Satta, G., Macis, M.D., et al., 2009. Serum lipoproteins and cancer. Nutr Metab. Cardiovasc. Dis. 19: 218-225.

Nanjee, M. N., and Miller, N. E. 1990. Evaluation of long-term frozen storage of plasma for measurement of highdensity lipoprotein and its subfractions by precipitation. Clinical Chemistry, 36(5), 783-788.

Ono, T. 1981. Serum-constituents analyses: effect of duration and temperature of storage of clotted blood. Clin. Chem. 27: $35-38$.

Paltiel, L., Ronningen, K.S., Meltzer, H.M., Baker, S.V., Hoppin, J.A. 2008. Evaluation of freeze thaw cycles on stored plasma in the biobank of the Norwegian mother and child cohort study. Cell Preserv Technol; 6:223-30.

Pini, C., Sommariva, D., Branchi, A., Scandiani, L., and Fasoli, A. 1990. Effects of serum storage on the determination of cholesterol. La Ricerca in clinica e in laboratorio, 20(1), 3744.

Pischon, T., Girman, C.J., Sacks, F.M., Rifai, N., Stampfer, M.J., et al., 2005. Nonhigh-density lipoprotein cholesterol and apolipoprotein B in the prediction of coronary heart disease in men. Circulation 112: 3375-3383.

Rudy, M.D., Kainz, M.J., Graeve, M., Colombo, S.M., Arts, M.T. 2016.
Handling and storage procedures have variable effects on fatty acid contents in fishes with different lipid quantities. PLoS ONE 11 (8): e0160497.

Santos, C.R., Schulze, A. 2012. Lipid metabolism in cancer. FEBS $J$ 279: 2610-2623.

Sasaki, G.C., Capuzzo, J.M. 1984. Degradation of artemia lipids under storage. Comp. Biochem. Physiol. 78: $525-531$.

Shai, I., Rimm, E.B., Hankinson, S.E., Curhan, G., Manson, J.E., et al., 2004. Multivariate assessment of lipid parameters as predictors of coronary heart disease among postmenopausal women: potential implications for clinical guidelines. Circulation 110: 2824-2830.

Simo, J. M., Camps, J., Vilella, E., Gomez, F., Paul, A., and Joven, J. 2001. Instability of lipoprotein (a) in plasma stored at -70 degrees $C$ : effects of concentration, apolipoprotein (a) genotype, and donor cardiovascular disease. Clinical Chemistry, 47(9), 1673-1678.

Stokes, Y. M., Salmond, C. E., Carpenter, L. M., and Welby, T. J. 1986. Stability of total cholesterol, high-densitylipoprotein cholesterol, and triglycerides in frozen sera. Clinical Chemistry, 32(6), 995-999.

Stokol, T., Nydam, V. 2005. Effect of anticoagulant and storage condition on bovine non-esterified fatty acid and bhydro- xybutyrate concentration in blood. J Dairy Sci; 88: 3139-3144.

Tiedink, H.G., Katan, M.B. 1989. Variability in lipoprotein concentrations in serum after prolonged storage at -20 degrees C. Clinica Chemica Acta, 180(2), 147155.

Walldius, G., Jungner, I. 2006 TheapoB/apoA-I ratio: a strong, new risk factor for cardiovascular disease and a target for lipid-lowering therapy-- 
a review of the evidence. $J$ Intern Med 259: 493-519.

Wood, P. D., Bachorik, P. S., Albers, J. J., Stewart, C. C., Winn, C., and Lippel, K. 1980. Effects of sample aging on total cholesterol values determined by the automated ferric chloride-sulfuric acid and Liebermann-Burchard procedures. Clinical Chemistry, 26(5), 592-597.

Young, D.S., Bermes, E.W. 1999. Specimen collection and processing: sources of biological variation. In: Burtis CA, Ashwood ER (Editors). Tietz textbook of clinical chemistry. Philadelphia: WB Saunders Company; 42-72.

Zivkovic, A. M., Wiest, M. M., Nguyen, U.T., Davis, R., Watkins, S.M., German, J.B. 2009. Effects of sample handling and storage on quantitative lipid analysis in human serum. Metabolomics; 5: 507516.

\section{How to cite this article:}

Ugwuezumba, P.C., P. Nwankpa, F.C. Emengaha, C.N. Ekweogu, C.C. Etteh and Chukwuemeka, O.G. 2018. Influence of Freeze-Thawing and Storage on Human Serum Lipid Analytes. Int.J.Curr.Microbiol.App.Sci. 7(10): 3287-3294.

doi: https://doi.org/10.20546/ijcmas.2018.710.381 